\title{
Motivasi Bermain Game dan Mediasi Orangtua dengan Kecenderungan Adiksi Video Game pada Anak
}

\author{
Asti Bhawika Adwitiya ${ }^{1}$, Supra Wimbarti ${ }^{2}$ \\ Fakultas Keguruan dan Ilmu Pendidikan, Universitas Muhammadiyah Jember \\ Jl. Karimata No. 49 Jember - Jawa Timur ${ }^{1}$ \\ Fakultas Psikologi, Universitas Gadjah Mada \\ J1. Sosio Humaniora Bulaksumur, Karang Malang, Caturtunggal, Kec. Depok, Kabupaten Sleman, Daerah \\ Istimewa Yogyakarta $55281^{2}$ \\ astiadwitiya@gmail.com¹ ${ }^{1}$,supra@ugm.ac.id ${ }^{2}$
}

\begin{abstract}
Abstrak
Adiksi video game menjadi perhatian para peneliti di dunia, ditandai munculnya adiksi video game dalam DSM 5 sebagai internet gaming disorder. Namun kebanyakan penelitian tersebut masih berfokus pada remaja meski saat ini, mayoritas anak-anak juga sudah bermain video game dengan berbagai tingkatan motivasi yang melatarbelakanginya. Orangtua sebagai pihak yang memfasilitasi anak dengan perangkat untuk bermain game perlu memediasi interaksi anak dengan game yang dimainkannya. Penelitian ini bertujuan untuk mengetahui hubungan antara motivasi bermain video game dan mediasi orangtua terhadap kecenderungan adiksi video game. Penelitian ini melibatkan 233 anak berusia 9-12 tahun (110 laki-laki ; 123 perempuan).. Analisis jalur yang dilakukan menunjukkan bahwa mediasi gatekeeping menjadi moderator hubungan antara motivasi bermain dengan kecenderungan adiksi video game.
\end{abstract}

Kata Kunci : fungsi eksekutif, prasangka, facebook

\begin{abstract}
Video game addiction has become the center of attention of the researchers across the world, marked by the emergence of video game addiction in DSM 5 as internet gaming disorder. Unfortunately, most of those research are still focused in adolescence even though the majority of children nowadays had also played video game with various level of underlying motivation. Parents as the facilitator of those children in using the device to play video game need to mediate the interaction of their children and the game they played. This research is aimed to determine the relationship between gaming motivation and parental mediation toward the video game addiction tendency. This research involved 233 children aged 9-12 years old (110 male; 123 female). Demographic questionnaire, gaming motivation scale, parental mediation scale, and video game addiction tendency scale were used in this research. Path analysis conducted showed that gatekeeping parental mediation became a moderator of the relationship between gaming motivation and video game addiction tendency.
\end{abstract}

Keywords: video game addiction, gaming motivation, parental mediation.

\section{PENDAHULUAN}

Video game merupakan salah satu sarana rekreasional yang banyak ditawarkan di zaman modern ini. Mayoritas orangtua di Asia Tenggara (90\%) memperbolehkan anak-anaknya untuk menggunakan gadget, yang umumnya digunakan untuk bermain video game(Unantenne, 2014). Anak-anak usia sekolah dasar biasa memainkan video game yang bisa diakses melalui internet (Horzum \& Bektas, 2014). Di salah satu kota besar di Indonesia, yaitu Yogyakarta, dari 251 anak berusia 9-12 tahun yang disurvey, 226 anak merupakan pemain video game aktif (Dewi, 
2018). Data-data tersebut memberikan gambaran penetrasi video game di Indonesia.

Game merupakan sarana hiburan yang menyenangkan dan memiliki berbagai kelebihan seperti dapat meningkatkan beberapa kemampuan kognitif dasar (Boot, Kramer, Simons, Fabiani, \& Gratton, 2008), kualitas pertemanan (Chou \& Tsai, 2007), kemampuan memahami hal baru (Green \& Bavelier, 2012), dan lain-lain. Namun, apabila digunakan tanpa kontrol atau pengawasan hingga jadi berlebihan, video game bisa mendatangkan berbagai dampak negatif bagi pemainnya. Salah satu dampak negatif game yang menjadi perhatian banyak pihak adalah mengenai risiko adiksi video game. Gangguan ini bahkan telah tercantum dalam DSM 5 sebagai salah satu kriteria diagnosa yang memerlukan penelitian lebih lanjut sebelum dapat dikatakan sebagai kriteria diagnosa yang baku (American Psychiatric Association, 2013). Dalam DSM 5 tersebut, adiksi video game ini disebut sebagai Internet Gaming Disorder (American Psychiatric Association, 2013).

Remaja laki-laki di Asia merupakan populasi yang dilaporkan memiliki prevalensi adiksi tertinggi menurut DSM-5 (American Psychiatric Association, 2013). Namun, jumlah ini bisa saja muncul akibat bias sampling dari berbagai penelitian, dimana kelompok usia ini jauh lebih sering diteliti dalam kasus adiksi game dibandingkan kelompok usia lainnya dan akibat belum adanya kriteria diagnosa yang baku (American Psychiatric Association, 2013; D. Griffiths, J. Kuss, \& L. King, 2012). Dari 74 penelitian yang direview oleh Griffiths et. al. (2012) serta Sublette dan Mullan (2012), sebanyak 46\% dari seluruh penelitian tersebut memiliki subjek remaja. Sisanya terbagi dalam kelompok usia anak-anak (6,75\%), dewasa awal (22\%), dewasa madya $(13,5 \%)$, dewasa akhir $(2,7 \%)$, dan sisanya tidak menyebutkan kelompok usia $(8,1 \%)$.

Banyaknya penelitian yang menyasar kelompok remaja dapat menunjukkan adanya potensi bias sampling yang terjadi. Tidak mengherankan adiksi dikatakan banyak terjadi pada remaja, karena memang kebanyakan yang dideteksi dengan adiksi adalah kelompok usia remaja. Padahal saat ini, anak-anak yang lebih muda sudah terekspos video game dari gadget-gadget yang diberikan orangtuanya. Dalam sebuah studi, $15 \%$ di antara anak-anak tersebut memainkan video game lebih dari 3 jam dalam sehari (Dewi, 2018). Meski bukan satu-satunya faktor penentu, durasi bermain video game merupakan salah satu indikator terjadinya adiksi video game (Griffiths, 2010; Lemmens, Valkenburg, \& Gentile, 2015; Lemmens, Valkenburg, \& Peter, 2009). Hal ini menunjukkan adanya potensi-potensi kecenderungan adiksi video game pada anak.

Anak-anak yang sudah mengenal teknologi sejak dini memiliki potensi yang besar untuk menjadi pemain video game aktif. Pemain video game aktif adalah seseorang yang memainkan video game menggunakan ponsel, perangkat genggam (handheld), konsol, PC, internet, maupun TV interaktif setidaknya sekali dalam enam bulan terakhir(Pratchett, 2005). Definisi yang luas ini digunakan untuk mencakup para pemain game dari yang ringan hingga berat.

Ada berbagai macam hal yang bisa memotivasi anak untuk bermain video game. Yee (2006) menyebutkan ada tiga motivasi utama yang mendasari mengapa mereka bermain video game. Alasan-alasan tersebut yaitu aspek pencapaian (achievement), sosial (social), dan penghayatan (immersion) yang mereka temukan di dalam game yang dimainkan.

Motivasi anak dalam bermain game dapat dijadikan sebagai salah satu prediktor dampakdampak negatif yang dialaminya akibat aktivitas tersebut (Hellström, Nilsson, Leppert, \& Slund, 2012). Apa yang membuat game sedemikian menariknya bagi anak dibandingkan kegiatan lain yang ditawarkan orangtua dan pemenuhan kebutuhan anak dengan kegiatan bermainnya dapat dijadikan acuan bagi orangtua dalam menentukan mediasi macam apa yang 
tepat bagi anak tersebut dan bagaimana mediasi tersebut dapat menghindarkan anak dari risiko adiksi video game.

Mediasi orangtua terhadap penggunaan video game anak menjadi sangat penting. Menurut (Unantenne, 2014) orangtua berharap gadget yang mereka berikan itu digunakan untuk tujuan lain yang dianggap lebih bermanfaat seperti untuk kepentingan edukasi. Tujuan ini juga didukung oleh penelitian terdahulu yang menunjukkan bahwa internet yang dapat diakses melalui gadget-gadget tersebut dapat memfasilitasi anak-anak untuk memperoleh informasi dalam menyelesaikan tugas sekolah dan meningkatkan performa akademik mereka (Shaffer, 2009). Alasan-alasan lain mengapa orangtua mengenalkan teknologi pada anak sejak dini adalah untuk memberikan hiburan pada anak, dan supaya mereka tetap sibuk dengan permainannya itu tanpa menggangu aktivitas orangtua (Unantenne, 2014).

Anak-anak, khususnya usia 9-12 tahun, memang akan menghabiskan waktu yang semakin sedikit dengan orangtuanya dan beralih ke interaksinya dengan teman-temannya, namun, orangtua tetap masih memegang peranan penting dalam kehidupan mereka (Santrock, 2011). Orangtua seharusnya menjadi 'penjaga gerbang' dan memberikan scaffolding karena anak sedang belajar bertanggung jawab atas dirinya dan mengatur kehidupannya sendiri (Huston \& Ripke, dalam Santrock, 2011). Di sinilah peran orangtua menjadi penting. Bagaimana orangtua bisa memediasi penggunaan gadget oleh anak supaya anak tidak terjerumus ke dalam adiksi game dan mengoptimalkan penggunaan fasilitas yang diberikan orangtua tersebut?

Dalam memediasi interaksi anak-anaknya dengan video game, orangtua menerapkan perilaku-perilaku mediasi yang tercakup dalam beberapa dimensi (Jiow, 2014; Jiow, Lim, \& Lin, 2017). Dimensi-dimensi tersebut antara lain aktivitas gatekeeping, discursive, investigative, dan diversionary.

Aktivitas gatekeeping merupakan praktik mediasi dimana orangtua menggunakan otoritasnya untuk membatasi atau juga memperbolehkan anak bermain game dengan menerapkan aturan dan regulasi. Aspek ini meliputi pengaturan kapan anak boleh bermain video game, berapa lama dia bisa memainkannya, membatasi akses anak pada video game, hanya membolehkan anak bermain setelah melakukan kewajibannya, membatasi dengan siapa anak bisa berinteraksi di dunia game, serta membatasi video game apa saja yang cocok dimainkan oleh anak.

Aktivitas discursive melibatkan diskusi antara orangtua dan anak mengenai penggunaan video game. Pada orangtua yang cenderung restriktif, diskusi ini digunakan untuk menginformasikan aturan dan regulasi yang diterapkan untuk anak. Pada orangtua yang cenderung menggunakan active mediation dan co-use, diskusi ini digunakan untuk menanamkan nilai dan kearifan pada anak, serta membuat hubungan orangtua-anak lebih bersifat dua arah.

Aktivitas investigative ini melibatkan pencarian informasi mengenai game yang dimainkan anak dengan mengawasi kegiatan bermain mereka serta mencari informasi dari berbagai sumber, seperti dengan melihat klasifikasi genre game maupun situs-situs pengasuhan. Pada orangtua yang cenderung restriktif, aktivitas investigatif akan membantu mereka memahami konten media seperti apa yang dilarang maupun diperbolehkan dan memahami apakah penerapan aturan dalam bermain game sudah efektif atau belum. Aktivitas investigatif pada orangtua yang cenderung menggunakan mediasi aktif biasanya dapat memfasilitasi diskusi lebih lanjut dengan anak yang bertujuan untuk meyakinkan anak supaya mereka bermain sesuai dengan game yang sepantasnya mereka mainkan. Selain itu, pada orangtua yang cenderung 
melakukan mediasi co-play dengan anaknya, aktivitas investigatif ini akan membantu mereka melakukan co-play dengan memahami game tersebut dan mempererat hubungan mereka dengan anak-anaknya.

Aktivitas diversionary merupakan usaha orangtua untuk mengalihkan perhatian anaknya dari video game ke aktivitas-aktivitas lainnya yang oleh orangtua dirasa lebih bermanfaat daripada sekedar bermain video game, seperti bermain di luar rumah mengikuti les, maupun mengikuti kegiatan ekstrakurikuler.

Dengan adanya pemahaman atas motivasi anak dalam bermain game dan mediasi orangtua atas penggunaan video game oleh anak, diharapkan gambaran mengenai kecenderungan adiksi pada anak yang diprediksikan oleh kedua variabel tersebut dapat diketahui. Perlu diperhatikan bahwa penelitian ini hanya meneliti kecenderungan adiksi pada anak, bukan menegakkan diagnosa adiksi atau tidak karena penegakan diagnosa semacam itu memerlukan asesmen yang lebih mendalam.

Keterkaitan antara kecenderungan adiksi video game pada anak, motivasi bermain game, dan mediasi orangtua menjadi hal yang menarik untuk diteliti. Pemahaman akan keterkaitan hal-hal tersebut diharapkan dapat meminimalisir risiko adiksi video game pada anak. Penelitian ini akan berusaha menjawab apakah motivasi bermain video game dan mediasi orangtua memiliki hubungan dengan kecenderungan adiksi video game pada anak.

\section{METODE}

Penelitian ini menggunakan teknik pengambilan sampel jenis purposive sampling sehingga didapatkan subjek penelitian berupa anak-anak pada rentang usia 9-12 tahun yang berada di Yogyakarta. Ada 260 anak yang turut berpartisipasi dalam penelitian ini, namun ada 27 anak yang tidak memenuhi kriteria. Dua puluh tujuh anak yang tidak memenuhi kriteria tersebut terdiri dari delapan orang bukan pemain game, 10 orang tidak mengisi skala secara lengkap, satu orang tidak memenuhi kriteria usia, satu orang tidak tinggal dengan orangtuanya, dan tujuh orang yang datanya terhitung sebagai outliers. Jumlah subjek penelitian ini adalah 233 orang dengan rincian jenis kelamin yaitu 110 laki-laki dan 123 perempuan.

Peneliti melakukan survey langsung pada para subjek penelitian. Anak-anak berusia 9-12 tahun tersebut diminta untuk mengisi kuesioner dan skala-skala yang telah disediakan. Penelitian ini menggunakan kuesioner demografis, skala motivasi bermain game, skala mediasi orangtua, dan skala kecenderungan adiksi video game. Kuesioner demografis mencakup informasi mengenai identitas subjek (misalnya: nama/inisial, usia, jenis kelamin, usia awal mengenal game, lama bermain game dalam sehari, dan game yang sering dimainkan).

Skala kecenderungan adiksi game bernama asli Internet Gaming Disorder. Skala ini merupakan skala yang disusun berdasarkan kriteria adiksi DSM-5 oleh Lemmens dkk. (2015). Skala ini sebenarnya dibuat untuk remaja, namun peneliti telah disesuaikan dan diujicobakan untuk anak-anak di Indonesia. Skala ini merujuk pada sembilan kriteria adiksi video game, yaitu preokupasi, toleransi, proses penarikan/withdrawal, persisten, pelarian diri/escape, permasalahan, penipuan/deception, diplacement, dan konflik. Setelah uji coba, skala final kecenderungan adiksi game yang digunakan dalam penelitian ini berjumlah total 18 aitem dengan koefisien Cronbach's Alpha 0,898.

Skala motivasi bermain game disusun sendiri oleh peneliti berdasarkan motivasi bermain game dari Yee (2006). Skala ini terdiri dari 3 komponen, yaitu pencapaian, sosial, dan penghayatan. Dimensi pencapaian terdiri dari tiga indikator, yaitu advancement, mechanic, dan 
competition. Dimensi sosial terdiri dari indikator socializing, relationship, dan teamwork. Adapun dimensi penghayatan terdiri dari discovery, role-playing, customization, dan escapism. Setelah uji coba, skala final motivasi bermain game yang digunakan dalam penelitian ini berjumlah total 19 aitem dengan koefisien Cronbach's Alpha 0,914.

Skala mediasi orangtua. Skala ini merupakan adaptasi dari skala mediasi orangtua karya Jiow (2014). Skala ini terdiri dari empat dimensi yaitu gatekeeping activities, discursive activities, investigative activities, dan diversionary activities. Setelah uji coba, skala final mediasi orangtua yang digunakan dalam penelitian ini berjumlah total 27 aitem dengan koefisien Cronbach's Alpha 0,918.

\section{HASIL}

Tabel 1.

Deskripsi data penelitian

\begin{tabular}{llrr}
\hline \multicolumn{1}{c}{ Kriteria } & \multicolumn{1}{c}{ Deskripsi } & Jumlah & Persentase \\
\hline \multirow{2}{*}{ Pekerjaan Ibu } & Ibu Bekerja & 145 & $62 \%$ \\
& Ibu Rumah Tangga & 88 & $38 \%$ \\
\hline \multirow{2}{*}{ Kepemilkan HP } & Memiliki HP pribadi & 189 & $81 \%$ \\
& Tidak memiliki HP pribadi & 43 & $18 \%$ \\
\hline \multirow{2}{*}{ Komunikasi Alternatif } & HP orangtua & 30 & $70 \%$ \\
& Lainnya & 13 & $30 \%$ \\
\hline & TK & 16 & $7 \%$ \\
& Kelas 1 & 23 & $10 \%$ \\
& Kelas 2 & 32 & $14 \%$ \\
Awal Kepemilikan HP & Kelas 3 & 51 & $22 \%$ \\
& Kelas 4 & 52 & $22 \%$ \\
& Kelas 5 & 19 & $8 \%$ \\
& Tidak menjawab & 40 & $17 \%$ \\
\hline \multirow{5}{*}{ Penggunaan HP } & Social Media & 75 & $32 \%$ \\
& Browsing & 109 & $47 \%$ \\
& Bermain Game & 28 & $12 \%$ \\
& Lainnya & 21 & $9 \%$ \\
\hline \multirow{5}{*}{ Waktu Luang } & Bermain Game & 87 & $37 \%$ \\
& Bermain di luar & 37 & $16 \%$ \\
& Menonton TV & 58 & $25 \%$ \\
& Belajar & 24 & $10 \%$ \\
& Lainnya & 27 & $12 \%$ \\
\hline \multirow{5}{*}{ Awal bermain game } & 0-3 tahun & 17 & $7 \%$ \\
& 4-6 tahun & 74 & $32 \%$ \\
& 7-9 tahun & 114 & $49 \%$ \\
& 10-12 tahun & 26 & $11 \%$ \\
\hline \multirow{5}{*}{ Kerangkat yang paling digunakan } & Komputer & 18 & $8 \%$ \\
& Laptop & 21 & $9 \%$ \\
& Tablet & 39 & $17 \%$ \\
& Smartphone & 135 & $58 \%$ \\
& Konsol genggam & 8 & $3 \%$ \\
& Konsol khusus (PS, Nintendo, dll) & 12 & $5 \%$ \\
\hline & Milik sendiri & 155 & $67 \%$
\end{tabular}




\begin{tabular}{llrr} 
& Milik orangtua & 48 & $21 \%$ \\
& Milik kakak & 7 & $3 \%$ \\
& Milik orang lain & 4 & $2 \%$ \\
& Milik bersama & 18 & $8 \%$ \\
\hline \multirow{3}{*}{ Durasi } & 1 jam & 84 & $36 \%$ \\
& $1-2$ jam & 79 & $34 \%$ \\
& $3-4$ jam & 48 & $21 \%$ \\
& $5-6$ jam & 9 & $4 \%$ \\
& $>6$ jam & 13 & $6 \%$ \\
\hline \multirow{2}{*}{ Tempat bermain } & Di dalam kamar & 156 & $67 \%$ \\
& Di ruang lain dalam rumah & 74 & $32 \%$ \\
& Warnet/rental & 2 & $1 \%$ \\
Game yang sering & Mobile Legend & 72 & $31 \%$ \\
dimainkan & Minecraft & 32 & $14 \%$ \\
& Piano Tiles & 8 & $3 \%$ \\
& Lainnya & 121 & $52 \%$ \\
\hline \multirow{2}{*}{ Rating game yang } & Not Rated & 8 & $3,4 \%$ \\
dimainkan & $3+$ & 92 & $39,5 \%$ \\
(berdasarkan rating IARC & $7+$ & 30 & $12,9 \%$ \\
Mei 2018) & $12+$ & 91 & $39,1 \%$ \\
& $16+$ & 12 & $5,2 \%$ \\
\hline \multirow{3}{*}{ Rekan bermain } & Sendirian & 123 & $53 \%$ \\
& Orangtua & 12 & $5 \%$ \\
& Saudara & 55 & $24 \%$ \\
& Teman & 43 & $18 \%$ \\
\hline
\end{tabular}

Berdasarkan tabel 1 di atas, dapat diketahui bahwa mayoritas subjek memiliki Ibu yang bekerja di luar rumah. Mayoritas anak-anak tersebut memiliki HP pribadi. Mereka yang tidak memilikinya biasa menggunakan HP orangtua, telepon rumah, maupun berbicara secara langsung. Mayoritas anak-anak tersebut memiliki HP pertamanya sejak kelas 3 dan 4 (masingmasing 22\%). Kebanyakan HP tersebut digunakan untuk browsing atau mencari informasi di internet. Kemungkinan hal tersebut terkait dengan penugasan yang diberikan oleh sekolah yang akan sangat dimudahkan dengan adanya internet dan untuk memenuhi rasa keingintahuan mereka sendiri dalam berbagai hal.

Mayoritas anak-anak menghabiskan waktu luangnya untuk bermain video game (37\%) atau menonton TV (25\%). Adapun awal mereka bermain video game antara usia 7-9 tahun (49\%). Data ini senada dengan kepemilikan HP anak-anak tersebut yang rata-rata mulai memiliki HP pada kelas 3 atau 4. Hp atau smartphone juga merupakan perangkat yang paling sering digunakan untuk bermain video game oleh anak-anak (58\%). Kebanyakan dari mereka menggunakan perangkat pribadinya untuk bermain video game (67\%). Anak yang lainnya meminjam HP milik orangtua, saudara, maupun orang lain untuk bermain. Mayoritas anakanak menjawab bermain kurang dari 1 jam (36\%) hingga sekitar 2 jam (34\%). Kebanyakan dari mereka bermain video game di dalam kamar (67\%). Hal tersebut dapat mempersulit proses mediasi yang dilakukan oleh orangtua.

Mayoritas anak-anak memainkan game Mobile Legend (31\%), Minecraft (32\%) dan Piano Tiles (8\%). Lima puluh satu persen lainnya memainkan berbagai video game baik di PC (Personal computer) maupun di Android/IOS. Banyaknya judul video game yang dimainkan 
tidak memungkinkan untuk dicantumkan satu per satu. Berdasarkan rating usia masing-masing game yang dirilis oleh IARC (International Age Ratings Coalition) dan ESRB (Entertainment Software Rating Board), mayoritas anak memainkan video game yang sesuai usianya $(52,4 \%)$, namun tidak sedikit anak yang memainkan game dengan rating di atas usia mereka seharusnya $(44,3 \%)$. Rating yang tinggi ini didominasi oleh game Mobile Legend yang diperuntukkan untuk anak usia 12+ karena mengandung moderate violence. Selain itu, menurut pengamatan peneliti, video game ini juga mengandung pornografi karena ada beberapa karakter perempuan yang digambarkan menggunakan pakaian yang menampakkan banyak bagian tubuh yang tidak seharusnya ditampakkan seperti paha dan lekukan payudara.

Kebanyakan anak-anak tersebut bermain sendirian (53\%), namun melihat trend video game yang dimainkan, yaitu video game yang dimainkan secara online, maka interaksi anak dengan orang asing pun tidak dapat terhindarkan. Setiap sesi permainan, mereka terekspos interaksi dengan orang lain melalui fitur chat maupun voice call yang dapat mereka lakukan sambil bermain video game tersebut. Beberapa anak memiliki orangtua yang menemani mereka bermain video game (5\%). Mereka menyebutkan bahwa ayah mereka yang menemani mereka bermain video game.

Selain data demografis di atas, data berupa skor para subjek juga diperoleh. Skor para subjek pun dikelompokkan menjadi kategori rendah, sedang, dan tinggi seperti yang tercantum pada tabel 2. Dari data pada tabel 2, dapat diketahui bahwa semua variabel penelitian kecuali motivasi bermain video game, mayoritas berara pada taraf sedang. Motivasi bermain video game menunjukkan angka yang tinggi pada mayoritas anak-anak tersebut.

Tabel 2.

Kategorisasi skor subjek

\begin{tabular}{lcccccc}
\hline \multirow{2}{*}{ Kategorisasi variabel penelitian } & \multicolumn{2}{c}{ Rendah } & \multicolumn{2}{c}{ Sedang } & \multicolumn{2}{c}{ Tinggi } \\
\cline { 2 - 7 } & frekuensi & \% & frekuensi & $\%$ & frekuensi & $\%$ \\
\hline Kecenderungan adiksi video game & 42 & $18 \%$ & 158 & $68 \%$ & 33 & $14 \%$ \\
Motivasi bermain video game & 20 & $9 \%$ & 88 & $38 \%$ & 125 & $54 \%$ \\
Mediasi_Gatekeeping & 45 & $19 \%$ & 159 & $68 \%$ & 29 & $12 \%$ \\
Mediasi_Investigative & 65 & $28 \%$ & 137 & $59 \%$ & 31 & $13 \%$ \\
Mediasi_Discursive & 53 & $23 \%$ & 137 & $59 \%$ & 43 & $18 \%$ \\
Mediasi_Diversionary & 50 & $21 \%$ & 155 & $67 \%$ & 28 & $12 \%$ \\
\hline
\end{tabular}

Teknik analisis jalur digunakan untuk mengetahui model yang dapat menjelaskan hubungan antar variabel dalam penelitian ini. Model yang dihipotesiskan dideskripsikan dalam Gambar 1. Hasil analisis data menggunakan analisis jalur menggunakan AMOS dideskripsikan pada tabel 3.

Hasil analisis data pada tabel 3 menunjukkan bahwa terdapat hubungan langsung antara motivasi dengan kecenderungan adiksi $(\mathrm{p}=0,01 ; \beta=0,376)$ dan mediasi gatekeeping dengan kecenderungan adiksi $(p=0,03 ; \beta=-0,491)$. Selain itu, interaksi antara motivasi dan mediasi gatekeeping juga menunjukkan adanya hubungan yang signifikan $(\mathrm{p}=0,006 ; \beta=0,878)$. 


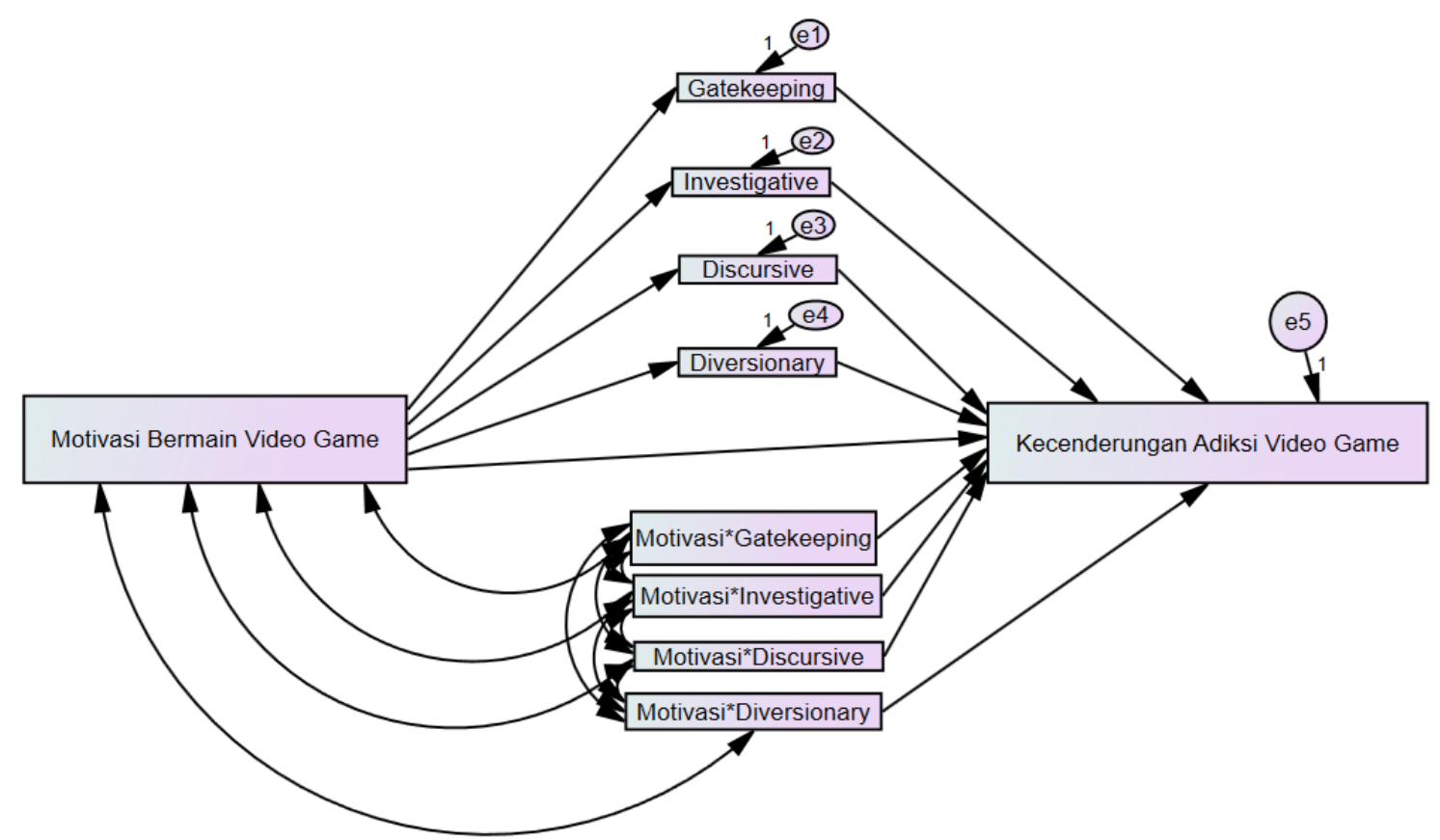

Gambar 1 Hubungan antar variabel

Tabel 3.

Hasil analisis data

\begin{tabular}{lllccccc}
\hline & & & $\begin{array}{c}\text { Standardized } \\
\text { Estimate }\end{array}$ & Estimate & S.E. & C.R. & P \\
\hline Diversionary & $<---$ & Motivasi & -.139 & -.028 & .013 & -2.142 & .032 \\
Discursive & $<---$ & Motivasi & -.028 & -.009 & .020 & -.434 & .664 \\
Investigative & $<---$ & Motivasi & -.081 & -.043 & .035 & -1.245 & .213 \\
Gatekeeping & $<---$ & Motivasi & -.092 & -.039 & .027 & -1.412 & .158 \\
Adiksi & $<---$ & Motivasi & .376 & .434 & .168 & 2.579 & .010 \\
Adiksi & $<---$ & Gatekeeping & -.491 & -1.356 & .630 & -2.153 & .031 \\
Adiksi & $<---$ & Investigative & .300 & .651 & .552 & 1.179 & .238 \\
Adiksi & $<---$ & Discursive & .032 & .119 & .797 & .149 & .881 \\
Adiksi & $<---$ & Diversionary & .206 & 1.173 & 1.197 & .980 & .327 \\
Adiksi & $<---$ & mot_medGK & .878 & .035 & .013 & 2.757 & .006 \\
Adiksi & $<---$ & mot_medInv & -.365 & -.013 & .011 & -1.120 & .263 \\
Adiksi & $<---$ & mot_medDis & -.182 & -.011 & .016 & -.687 & .492 \\
Adiksi & $<---$ & mot_medDiv & -.403 & -.038 & .023 & -1.636 & .102 \\
\hline
\end{tabular}

Pengaruh variabel gatekeeping sebagai moderator dan variabel motivasi terhadap kecenderungan adiksi yang sama-sama signifikan menunjukkan bahwa variabel gatekeeping berperan sebagai variabel moderator semu (Quasi moderator). Artinya, variabel gatekeeping dapat berperan sebagai variabel eksogen maupun moderator. Mediasi orangtua tidak menjadi variabel mediator hubungan antara motivasi bermain dengan kecenderungan adiksi video game. Hal ini tampak dari pengaruh langsung motivasi terhadap kecenderungan adiksi video game $(0,376)$ yang lebih besar dari pengaruh tidak langsungnya $(-0,01)$. 
Sementara itu, dimensi lain dari mediasi orangtua tidak menunjukkan adanya hubungan yang signifikan dengan kecenderungan adiksi video game. Interaksi dimensi-dimensi ini dengan motivasi bermain video game tidak menunjukkan hubungan yang signifikan pula. Oleh karena itu, dapat disimpulkan bahwa mediasi gatekeeping merupakan mediasi orangtua yang memiliki peran dalam memoderatori hubungan antara motivasi bermain video game dengan kecenderungan adiksi video game.

\section{PEMBAHASAN}

Tujuan utama penelitian ini adalah untuk menentukan hubungan antara motivasi bermain video game dan mediasi orangtua dengan kecenderungan adiksi video game pada anak-anak usia akhir di Daerah Istimewa Yogyakarta. Hasil analisis di atas menunjukkan bahwa selain motivasi bermain video game, mediasi gatekeeping memiliki pengaruh yang signifikan terhadap adiksi video game, dimana semakin tinggi gatekeeping yang dilakukan orangtua, maka semakin rendah kecenderungan adiksi video game pada anak. Selain itu, gatekeeping juga memoderatori hubungan antara motivasi bermain dengan kecenderungan adiksi video game pada anak. Kecenderungan adiksi video game pada anak yang memiliki motivasi tinggi untuk bermain dapat meningkat maupun menurun tergantung pada mediasi gatekeeping yang dilakukan orangtua.

Mediasi gatekeeping yang merupakan salah satu dimensi dari mediasi orangtua yang dicetuskan oleh Jiow (2014;2017). Mediasi gatekeeping ini memiliki kesamaan indikator dengan mediasi restriktif pada menurut penelitian sebelumnya yang serupa mendukung temuan ini. Penelitian tersebut menyatakan bahwa dari sekian banyak jenis mediasi orangtua yang ada, hanya mediasi restriktif yang dapat memberikan pengaruh signifikan terhadap penggunaan video game secara tidak sehat (Benrazavi, Teimouri, \& Griffiths, 2015).

Mayoritas anak pada masa kini menggunakan video game sebagai sarana bermainnya. Berdasarkan data penelitian ini, hanya 8 dari 260 anak yang mengisi kuesioner (3\%) yang mengaku bukan pemain game. Selain itu data penelitian ini juga menunjukkan bahwa mayoritas anak-anak tersebut memiliki motivasi bermain yang tinggi (54\%) Motivasi bermain video game mendorong anak-anak tersebut untuk bermain video game. Sementara, motivasi yang tinggi dapat memprediksikan kecenderungan adiksi video game yang tinggi pula. Hal menarik yang ditemukan di sini adalah bahwa sebagai mediator, mediasi orangtua justru memperkuat hubungan antara motivasi dengan kecenderungan adiksi video game. Dengan kata lain, apabila seorang anak memiliki motivasi bermain video game yang tinggi memperoleh mediasi gatekeeping yang tinggi pula dari orangtuanya, maka risikonya untuk memiliki kecenderungan adiksi video game akan semakin tinggi.

Mediasi gatekeeping yang bersifat restriktif dapat meningkatkan hubungan antara motivasi dan kecenderungan adiksi dimungkinkan karena mediasi gatekeeping tidak dapat mengakomodasi keinginan anak untuk bermain game. Motivasi anak untuk bermain game ini bisa bermacam-macam, ada yang karena memang ingin bermain (achievement dan immersion), maupun karena teman-temannya juga memainkan game tertentu (social). Anak yang memiliki motivasi yang tinggi untuk bermain video game sudah memasuki tahap persiapan untuk menjadi adiksi dimana ia sudah memiliki kecenderungan yang tinggi untuk mengulangi kegiatan bermain game tersebut . Hal ini sesuai dengan tahapan adiksi DiClemente (2003).

Ketika anak sudah memiliki motivasi yang tinggi untuk bermain video game dalam tahap persiapan tersebut, larangan-larangan dari orangtua yang merupakan ciri mediasi gatekeeping 
akan menjadi tantangan tersendiri bagi anak untuk dapat memuaskan keinginannya. Ketika ia bisa melewati tantangan tersebut dan berhasil memuaskan keinginannya ia merasa semakin senang dan percaya diri untuk bermain video game karena merasa bisa mengatasi konsekuensi negatif yang mengikutinya. Begitu pula bila tantangan tersebut tidak ada, maka faktor yang memperkuat motivasinya untuk bermain video game hingga meningkatkan risiko kecenderungan adiksinya pun tidak ada.

Proses mediasi gatekeeping yang dilakukan oleh orangtua pada anak-anak yang memiliki motivasi tinggi untuk bermain menimbulkan kemungkinan untuk memicu konflik antara orangtua dan anak. Hal ini dapat dijelaskan dengan keterkaitan antar variabel yang ada. Semakin tinggi motivasi anak untuk bermain, maka semakin tinggi pula kecenderungan adiksi video game-nya. Anak-anak dengan kecenderungan adiksi video game yang tinggi anak menampakkan lebih banyak gejala-gejala adiksi video game seperti yang dijelaskan dalam kriteria-kriteria adiksi dalam DSM 5. Dari kriteria-kriteria tersebut, yang menimbulkan masalah dengan orang-orang di sekitar anak adalah timbulnya konflik dan kebohongan.

Proses mediasi gatekeeping ini sangat rentan menimbulkan konflik dan kebohongan karena adanya batasan-batasan yang diberikan oleh orangtua terhadap anak-anak tersebut. Konflik yang terjadi dapat menjurus ke perilaku agresif anak, misalnya ketika orangtua meminta anak untuk menghentikan permainannya. Perilaku agresif ini dapat timbul karena kemampuan anak untuk menahan diri atau kontrol diri anak tidak bekerja dengan baik. Perilaku tersebut terjadi meski anak tahu bahwa perilaku agresif adalah perbuatan yang buruk.

Hal ini dapat dijelaskan dengan fungsi executive functioning pada anak. Executive functioning merupakan sekumpulan proses mental yang digunakan, jika seseorang tersebut bersandar pada insting, maka akan menimbulkan dampak buruk maupun tidak tercapainya tujuan yang diinginkan (Diamond, 2013). Baler dan Volkow (2006) menyatakan bahwa pada individu dengan adiksi, terdapat gangguan pada executive function-nya.

Kemampuan anak untuk menahan diri merupakan salah satu aspek dari executive function, yaitu response inhibition. Ketidakmampuan anak untuk mengontrol keinginannya untuk bermain game sehingga menjurus ke arah adiksi merupakan salah satu tanda terganggunya fungsi response inhibition ini. Anak tahu bermain video game secara berlebihan hingga menimbulkan gejala adiksi seperti konflik dengan orangtua maupun gangguan lainnya bukanlah hal yang baik. Namun fokus anak tidak terletak pada dampak negatif tersebut sehingga ia tetap melanjutkan kegiatan bermainnya seperti biasa.

Pada anak-anak dengan motivasi yang rendah, mereka sedang berada pada tahap kontemplasi menurut DiClemente (2003). Pada tahap ini mereka sedang dalam proses mempertimbangkan untuk bermain video game secara terus menerus. Proses ini bisa terjadi dalam waktu yang lama (DiClemente, 2003). Tahap kontemplasi ini bisa maju mundur ke tahap persiapan maupun tahap pra-kontemplasi. Mediasi gatekeeping dari orangtua akan memberikan pertimbangan pada anak untuk tetap berada pada tahap kontemplasi ini, atau membantu anak secara sadar mundur ke tahap pra-kontemplasi dimana anak tidak mempertimbangkan untuk bermain game karena pilihannya sendiri. Namun, tanpa gatekeeping potensi anak untuk maju ke tahap persiapan menuju adiksi akan semakin besar karena anak tidak memperoleh alasan untuk mempertimbangkan dampak buruk bermain game.

\section{KESIMPULAN}


Motivasi bermain video game berpengaruh positif pada kecenderungan adiksi video game. Semakin tinggi motivasi anak untuk bermain, semakin tinggi kecenderungan adiksi video game pada anak, begitu pula sebaliknya. Mediasi gatekeeping memiliki pengaruh negatif pada kecenderungan adiksi video game. Selain itu, mediasi gatekeeping ini juga menjadi moderator hubungan antara motivasi dengan kecenderungan adiksi video game.

\section{DAFTAR PUSTAKA}

American Psychiatric Association. (2013). Diagnostic and statistical manual of mental disorders (5th ed.). Washington DC: American Psychiatric Association.

Baler, R. D., \& Volkow, N. D. (2006). Drug addiction: the neurobiology of disrupted selfcontrol. Trends in Molecular Medicine, 12(12), 559-566. https://doi.org/10.1016/j.molmed.2006.10.005

Benrazavi, R., Teimouri, M., \& Griffiths, M. D. (2015). Utility of Parental Mediation Model on Youth's Problematic Online Gaming. International Journal of Mental Health and Addiction, 13(6), 712-727. https://doi.org/10.1007/s11469-015-9561-2

Boot, W. R., Kramer, A. F., Simons, D. J., Fabiani, M., \& Gratton, G. (2008). The effects of video game playing on attention, memory, and executive control. Acta Psychologica, 129(3), 387-398. https://doi.org/10.1016/j.actpsy.2008.09.005

Chou, C., \& Tsai, M. J. (2007). Gender differences in Taiwan high school students' computer game playing. Computers in Human Behavior, 23(1), 812-824. https://doi.org/10.1016/j.chb.2004.11.011

D. Griffiths, M., J. Kuss, D., \& L. King, D. (2012). Video Game Addiction: Past, Present and Future. Current Psychiatry Reviews, 8(4), 308-318. https://doi.org/10.2174/157340012803520414

Dewi, P. A. (2018). Peran adiksi video game terhadap agresivitas yang dimoderatori oleh persepsi terhadap mediasi orang tua pada masa anak-anak akhir di Daerah Istimewa Yogyakarta. Universitas Gadjah Mada.

Diamond, A. (2013). Executive functions. Annual Reviews of Psychology, (64), 135-168. https://doi.org/10.1146/annurev-psych-113011-143750

DiClemente, C. . (2003). Addiction and Change: How Addictions Develop and Addicted People Recover. New York: Guilford Press.

Green, C. S., \& Bavelier, D. (2012). Learning, attentional control, and action video games. Current Biology, 22(6), R197-R206. https://doi.org/10.1016/j.cub.2012.02.012

Griffiths, M. D. (2010). The role of context in online gaming excess and addiction: Some case study evidence. International Journal of Mental Health and Addiction, 8(1), 119-125. https://doi.org/10.1007/s11469-009-9229-x

Hellström, C., Nilsson, K. W., Leppert, J., \& Slund, C. (2012). Influences of motives to play and time spent gaming on the negative consequences of adolescent online computer gaming. Computers in Human Behavior, 28(4), 1379-1387. 
https://doi.org/10.1016/j.chb.2012.02.023

Horzum, M. B., \& Bektas, M. (2014). Examining the internet use aim and internet parental style of primary school students in terms of various variables. Croatian Journal of Education, 16(3), 745-778.

Jiow, H. J. (2014). Parental mediation of video gaming in Singapore (Doctoral Thesis). National University of Singapore, Singapore.

Jiow, H. J., Lim, S. S., \& Lin, J. (2017). Level Up! Refreshing Parental Mediation Theory for Our Digital Media Landscape. Communication Theory, 27(3), 309-328. https://doi.org/10.1111/comt.12109

Lemmens, J. S., Valkenburg, P. M., \& Gentile, D. A. (2015). The internet gaming disorder scale. Psychological Assessment, 27(2), 567-582. https://doi.org/10.1037/pas0000062

Lemmens, J. S., Valkenburg, P. M., \& Peter, J. (2009). Development and validation of a game addiction scale for adolescents. Media Psychology, 12(1), 77-95. https://doi.org/10.1080/15213260802669458

Pratchett, R. (2005). Gamers in the UK: Digital play, digital lifestyles. $B B C$. Retrieved from https://crystaltips.typepad.com/wonderland/files/bbc_uk_games_research_2005.pdf

Santrock, J. . (2011). Life-span Development (11th ed.). New York: McGraw-Hill.

Shaffer, D. . (2009). Social and Personality Development (6th ed.). Belmont: Wadsworth.

Sublette, V. A., \& Mullan, B. (2012). Consequences of Play: A Systematic Review of the Effects of Online Gaming. International Journal of Mental Health and Addiction, 10(1), 3-23. https://doi.org/10.1007/s11469-010-9304-3

Unantenne, N. (2014). Mobile Device Usage Among Young Kids: A Southeast Asia Study. Asianparent Insights Mobile. The Asian Parent Insight. Retrieved from https://s3-apsoutheast-1.amazonaws.com/tap-sg-

media/theAsianparent+Insights+Device+Usage+A+Southeast+Asia+Study+November+ 2014.pdf

Yee, N. (2006). Motivations for play in online games. Cyberpsychology and Behavior, 9(6), 772-775. https://doi.org/10.1089/cpb.2006.9.772 